\title{
Parasite diversity in Oxydoras niger (Osteichthyes: Doradidae) from the basin of Solimões River, Amazonas state, Brazil, and the relationship between monogenoidean and condition factor
}

\author{
Silva, AMO. ${ }^{a}$, Tavares-Dias, M. ${ }^{b *}$, Jerônimo, GT. ${ }^{c}$ and Martins, ML. ${ }^{c}$ \\ anstituto de Saúde e Biotecnologia, Universidade Federal do Amazonas - UFAM, \\ Estrada Coari-Mamiá, 305, CEP 69460-000, Coari, AM, Brazil \\ 'Laboratório de Aquicutura e Pesca - Embrapa Amapá, \\ Rod. Juscelino Kubitschek, Km 5, 2600, CEP 68903-419, Macapá, AP, Brazil \\ ${ }^{c}$ Laboratório Aquos - Sanidade de Organismos Aquáticos, Universidade Federal de Santa Catarina - UFSC, \\ Rod. Admar Gonzaga, 1346, CEP 88040-900, Florianopolis, SC, Brazil \\ *e-mail: marcostavares@cpafap.embrapa.br
}

Receveid October 18, 2010 - Accepted November 24, 2010 - Distributed August 31, 2011

(With 1 figure)

\begin{abstract}
This study describes the parasitic fauna of Oxydoras niger from the Coari Lake, tributary of the medium Solimões River, State of Amazonas, Brazil, and the relationship between the number of Monogenoidea and the condition factor. From a total of 27 examined fish, $70.3 \%$ were parasitised by at least one parasite species as follows: Ichthyophthirius multifiliis (Protozoa), Chilodonella sp. (Protozoa), Cosmetocleithrum gussevi, C. confusus, C. parvum and Cosmetocleithrum sp. (Monogenoidea), Paracavisona impudica (Acanthocephala), Cucullanus grandistomis (Nematoda), Proteocephalus kuyukuyu (Cestoda) and Dadaytrema sp. (Digenea). Monogenoidea helminthes were the most prevalent parasite when compared to protozoan and intestinal helminthes. This study showed that $O$. niger has a great parasite diversity composed mainly of monogenoideans followed by acanthocephalan and digenean. This is the first record of Dadaytrema in $O$. niger from the Brazilian Amazon. There was a positive correlation between the number of monogenoideans and the condition factor $(\mathrm{Kn})$ of fish, and with this mean intensity of infection, fish welfare was not affected.
\end{abstract}

Keywords: Amazon, freshwater fish, infection, Monogenoidea, condition factor.

Diversidade de parasitos em Oxydoras niger (Osteichthyes: Doradidae) da bacia do rio Solimões, estado do Amazonas, Brasil, e relação entre Monogenoidea e fator de condição

\section{Resumo}

Este estudo descreve a fauna parasitária de Oxydoras niger do lago Coari, tributário do médio rio Solimões, estado do Amazonas, Brasil, e a relação entre o número de Monogenoidea e o fator de condição. De um total de 27 peixes examinados, 70,3\% estavam parasitados por pelo menos uma espécie de parasito como segue: Ichthyophthirius multifiliis (Protozoa), Chilodonella sp. (Protozoa), Cosmetocleithrum gussevi, C. confusus, C. parvum and Cosmetocleithrum sp. (Monogenoidea), Paracavisona impudica (Acanthocephala), Cucullanus grandistomis (Nematoda), Proteocephalus kuyukuyu (Cestoda) and Dadaytrema sp. (Digenea). Helmintos monogenóideos foram os mais prevalentes quando comparados com protozoários e helmintos intestinais. Este estudo mostrou que $O$. niger apresenta grande diversidade de parasitos composta principalmente de monogenóideos seguidos de acantocéfalos e digenéticos. Este foi o primeiro relato de Dadaytrema em O. niger na Amazônia brasileira. Foi observada correlação positiva entre o número de monogenóideos e o fator de condição $(\mathrm{Kn})$ e nessa intensidade média de infecção o bem-estar do peixe não foi afetado.

Palavras-chave: Amazônia, peixe de água doce, infecção, Monogenoidea, fator de condição. 


\section{Introduction}

Fish are important for the human population in trade and economy, and constitute the main source of food in different countries, and especially in the Amazon. As the human population inevitably increases, so too has the demand for fish as a source of protein increased.

Among Amazon fish, Oxydoras niger Valenciennes, 1821 (Siluriformes: Doradidae) commonly called "cuiucuiu", is known for its good meat that looks like salmon in colour, and its importance in public markets. Distributed in the Basins of Amazonas River, Araguaia-Tocantins and Prata, considered the largest Doradidae in Amazon, is sought after for its large size, reaching up to $1.2 \mathrm{~m}$ long and $20 \mathrm{~kg}$ in weight. Its food consists of debris from the river bottom and aquatic invertebrates, mainly insect larvae, and it reproduces at the beginning of the rainy season (Santos et al., 2006).

Despite the importance of this fish for the population in some regions of the Amazon, little is known of its parasitic fauna. Parasitic fauna of this fish is composed of Monogenoidea Cosmetocleithrum confusus Kritsky, Thatcher and Boeger, 1986, Cosmetocleithrum gussevi Kritsky, Thatcher and Boeger, 1986, Cosmetocleithrum parvum Kritsky, Thatcher and Boeger, 1986, Cosmetocleithrum rarum Kritsky, Thatcher and Boeger, 1986 and Cosmetocleithrum sobrinus Kritsky, Thatcher and Boeger, 1986 (Kritisky et al., 1986); Branchiura Dolops longicauda Heller, 1857; Cestoda Proteocephalus kuyukuyu Woodland, 1934; Acanthocephala Paracavisoma impudica Diesing, 1851, Kritcher, 1957 (Thatcher, 2006) and Nematoda Cucullanus grandistomis Ferraz and Thatcher, 1988 (Ferraz and Thatcher, 1988; Thatcher, 2006). Though some reports on its parasitic fauna exist, nothing is known either of the parasitological indexes, nor of the condition factor in $O$. niger.

Fish may present a great diversity of parasites which depend on the fish species, food habit, temperature, climate and rainfall (Martins et al., 2009; Takemoto et al., 2009). They act as a host for a large number of parasites with varied strategies in their life-cycle. Among the factors that contribute to disease dissemination in fish are host susceptibility, fish stocking densities, the duration of the infectious process and introductions, as mentioned by Reno (1998).

Consequently, studies on fish parasitology are needed to improve the knowledge of the relationships between host and parasites (Pavanelli et al., 2004; Takemoto et al., 2004, 2009; Martins et al., 2009). These studies can indicate the fish food habit, as has been reported by Machado et al. (1996), Takemoto et al. (2004, 2009) and Martins et al. (2009). Piscivorous fish occupy the top of the food web and may present more chance of infection (Machado et al., 1996; Martins et al., 2009), while omnivorous fish present lower risks of infection by the fact that they are primary consumers in the food web (Feltran et al., 2004; Takemoto et al. (2009).

This study describes the parasitic fauna in $O$. niger from the Coari Lake, in the medium Solimões River basin,
Amazonas state, Brazil. The prevalence, mean intensity of infection and condition factor relative to monogenoideans helminthes are also discussed.

\section{Material and Methods}

Twenty-seven Oxydoras niger (350 to $1,540 \mathrm{~g}$ and 30.5 to $49.5 \mathrm{~cm}$ ) were collected from September to November 2009 with a net (Authorized by Ibama 11884-1) from the Coari lake, municipality of Coari (04 ${ }^{\circ} 00^{\prime} 582^{\prime \prime} \mathrm{S}$ and $063^{\circ} 19^{\prime} 225^{\prime}$ W), in the medium Solimões River basin, in the state of Amazonas, Brazil, and transported to the Health and Biotechnology Institute of the Federal University of Amazonas, Coari, AM, for parasitological examination. During the period, the water temperature varied from 27.7 to $28.9^{\circ} \mathrm{C}$ and dissolved oxygen from 4.2 to $5.3 \mathrm{mg} / \mathrm{L}$.

All fish were measured and weighed, and necropsied when observation of the internal organs was carried out. The gills and the viscera were removed and kept in saline solution $0.65 \%$ for examination under the microscope. Parasites found were isolated and fixed according to Eiras et al. (2006) for quantification (Tavares-Dias et al., 2001a,b) and identified according to Thatcher (1979, 2006), Kritsky et al. (1986), Rego et al. (1999), Ferraz and Thatcher (1988). Ecological terms followed Bush et al. (1997) and Rohde et al. (1995).

The length and weight of the hosts were used to calculate the relative condition factor $(\mathrm{Kn})$ of those parasitised and non-parasitised according to Le Cren (1951). Spearman's rank correlation coefficient rs was used to determine the possible correlations between the total length of the host and the number of monogenoidean parasites, and to verify correlations between the number of monogenoideans and the relative condition factor (Zar, 1999).

\section{Results}

From a total of 27 examined fish, $70.3 \%(n=19)$ were parasitised by at least one parasite species as follows: Ichthyophthirius multifiliis Fouquet, 1876 (Protozoa: Ciliophora), Chilodonella Strand, 1926 (Protozoa: Ciliophora); Cosmetocleithrum gussevi Kritsky, Thatcher and Boeger, 1986, Cosmetocleithrum confusus Kritsky, Thatcher and Boeger, 1986, Cosmetocleithrum parvum Kritsky, Thatcher and Boeger, 1986 and Cosmetocleithrum sp. (Monogenoidea: Dactylogyridae) possibly Cosmetocleithrum bulbocirrus Kritsky, Thatcher and Boeger, 1986. Intestinal infection represented $18.5 \%$ of the total fish examined composed of Paracavisona impudica (Diesing, 1851) Kritcher, 1957 (Acanthocephala: Echinorhynchidae), 3.7\% by Cucullanus grandistomis Ferraz and Thatcher, 1988 (Nematoda: Cucullanidae), $14.8 \%$ by Dadaytrema (Travassos, 1931) Thatcher, 1979 (Digenea: Cladorchiniidae) and 3\% by Proteocephalus kuyukuyu Woodland, 1935 (Cestoda: Proteocephalidae). Monogenoidean helminthes were the most abundant parasites with $70.3 \%$ of prevalence and mean intensity of 702.1 parasites, varying from 137 to 1,488 (Table 1). 
Table 1. Parasitological indexes in Oxydoras niger from the Solimões River basin, Amazonas state, Brazil.

\begin{tabular}{lcccccc}
\hline \multicolumn{1}{c}{ Parasites } & EF/PF & P $(\%)$ & TNP & MI \pm SD & Range & MRD \\
\hline Ichthyophthirius multifilis & $27 / 1$ & 3.7 & 50 & $50.0 \pm 0.0$ & - & 0.0036 \\
Chilodonella sp. & $27 / 1$ & 3.7 & 60 & $60.0 \pm 0.0$ & - & 0.0043 \\
Cosmetocleithrum spp. & $27 / 19$ & 70.3 & 13,341 & $702.1 \pm 387.8$ & $137-1,488$ & 0.9775 \\
Cucullanus grandistomis & $27 / 1$ & 3.7 & 9 & $9.0 \pm 0.0$ & - & 0.0006 \\
Paracavisona impudica & $27 / 5$ & 18.5 & 161 & $32.2 \pm 46.8$ & $3-115$ & 0.0118 \\
Dadaytrema sp. & $27 / 4$ & 14.8 & 25 & $6.0 \pm 3.2$ & $3-10$ & 0.0018 \\
Proteocephalus kuyukuyu & $27 / 1$ & 3.7 & 1 & $1.0 \pm 0.0$ & - & 0.000 \\
\hline
\end{tabular}

EF: examined fish; PF: parasitised fish; SD: Standard Deviation; P: Prevalence; TNP: total number of parasites; MI: mean intensity of infection; and MRD: Mean relative dominance.

There was no significant difference in the relative condition factor $(\mathrm{Kn})$ of parasitised $(\mathrm{Kn}=1.00)$ and nonparasitised fish $(\mathrm{Kn}=1.00)$, as well as no correlation between the number of monogenoidean number and total length ( $r s=-0.0820, p=0.732$ ) of the hosts. However, a significant positive correlation was observed between the number of monogenoidean and the relative condition factor $(\mathrm{Kn})$ of the hosts (Figure 1).

\section{Discussion}

In O. niger from the Solimões River, Monogenoideans were the most prevalent (70.3\%), followed by Acanthocephala (18.5\%), Digenea (14.8\%), Protozoa (6.6\%), Nematoda (3.7\%) and Cestoda (3.7\%). Nevertheless, Luque and Poulin (2007) related Digenea (33.5\%) as the most abundant parasite in the Brazilian freshwater native fish followed by Nematoda (26.0\%), Monogenoidea (15.2\%), Crustacea (12.5\%), Cestoda (11.0\%) and Acanthocephala (5.0\%). Oxydoras niger showed low prevalence and intensity of infection by I. multifiliis and Chilodonella. However, elevated intensities of these protozoan parasites are common in cultured fish (Tavares Dias et al., 2001a; Martins et al., 2002; Tavares-Dias et al., 2010), where the inadequate handling of water can facilitate their reproduction.

An important characteristic of the monogenoideans is that of their host specificity (Takemoto et al., 2004, 2009; Thatcher, 2006), also serving as a taxonomic indicator. Parasites of the genus Cosmetocleithrum are mostly found in Siluriformes fish (Krytisky et al., 1986), mainly Doradidae and Pimelodidae (Suriano and Incorvaia, 1995; Thatcher, 2006). Five species of monogenoideans belonging to the genus Cosmetocleithrum were recorded for the first time in O. niger and Pterodoras granulosus Valenciennes, 1821 in Janauacá Lake, Amazonas state, Brazil (Kritsky et al., 1986). Until now, there have been no studies of parasitic fauna of $O$. niger from the medium Solimões River, in the state of Amazonas, Brazil.

Knowledge of the condition factor is an important tool for the study of fish welfare reflecting directly on its physiology (Le Cren, 1951; Dias et al., 2004). Thus, the condition factor is a tool used to evaluate the relationship between host and parasite (Lizama et al., 2007). No correlation between the number of monogenoidean and

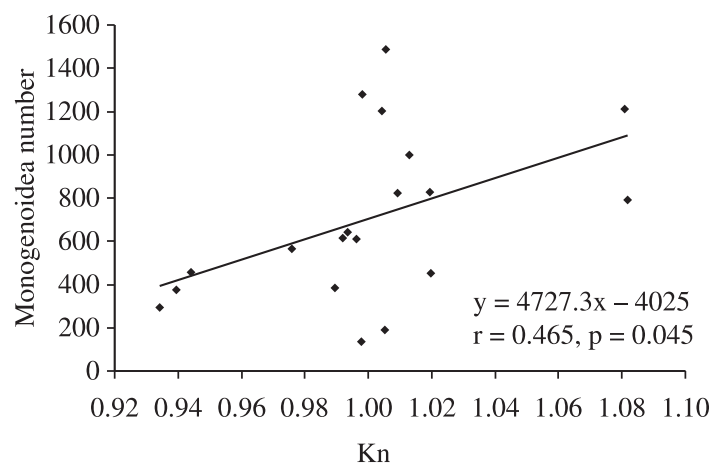

Figure 1. Correlation between Kn and Monogenoidea helminthes in the gills of Oxydoras niger from the Solimões River basin, Amazonas state, Brazil.

total length of the host was found in $O$. niger in the present study, and the relative condition factor $(\mathrm{Kn})$ of parasitised and non-parasitised fish was also similar. In contrast, the number of monogenoidean showed a positive correlation with $\mathrm{Kn}$. Therefore, these results indicate that these parasites did not affect the health of fish. Similarly, Azevedo et al. (2007) did not find correlation between the abundance of the monogenoideans and acanthocephalans in Astronotus ocellatus Agassiz, 1831 from the Guandu River, RJ. However, abundance of Cichidogyrus presented a negative correlation with the standard length and also with the $\mathrm{Kn}$ in cultured Oreochomis niloticus Linnaeus, 1757 (Lizama et al., 2007).

Four species of monogenoideans (C. gussevi, C. confusus, $C$. parvum and C. bulbocirrus) were found and presented the greatest intensities in $O$. niger in the present study. They showed a positive correlation with Kn. This elevated mean intensity was similar to that related in cultured Piaractus mesopotamicus Holmberg, 1884 (Tavares-Dias et al., 2001b) and larger than that related in A. ocellatus in Guandu River, RJ (Azevedo et al., 2007) and ornamental fish from the Negro River, AM (Tavares-Dias et al., 2010). Our results confirm that monogenoideans are among the most common fish parasite that occurs in several environments. High infection levels observed in this study show that they can be present sometimes in a quantity greater than that observed in cultured fish. Its reproduction can be favoured 
by the lentic habitat since these parasites have a direct life-cycle (Pavanelli et al., 2004). Graça and Machado (2007) suggested that the fish habitat feeding on the bottom facilitate the suspension of monogenoidean eggs. In fact, this occurred in cichlid fish from the Ingá Park, Maringá (PR). This may explain the elevated number of monogenoidean in $O$. niger in this work. The food habit on predating debris and invertebrates from the bottom of the River is likely responsible for ressuspension of monogenoidean eggs.

On the other hand, Nematoda are the most frequent endohelminthes in populations of wild fish, constituting a significant part of parasite fauna of the hosts in several environments. In $O$. niger, low infection levels were observed by $C$. grandistomis as also reported by Machado et al. (1996) in fish from the high Paraná River parasitised by $C$. pinnai, Procamallanus inopinatus Travassos, Artigas and Pereira, 1928, P. iheringi Travassos, Artigas and Pereira, 1928, Piavussunema schubarti Kohn, Gomes and Motta, 1968, by Santos et al. (2003) in fish from the Paraguai River, MS parasitised by Cucullanus sp. and by Bachmann et al. (2007) in Pimelodus maculatus Lacépède, 1803 parasitised by $P$. pimelodus Pinto, Fabio, Noronha and Tayt-Son Rolas, 1974. However, high parasitological indexes by Cucullanus pinnai Travassos, Artigas and Pereira, 1928 in P. maculatus from the Guandu River, RJ (Santos et al., 2007) and by P. inopinatus in Leporinus friderici Bloch, 1794 and Leporinus obtusidens Valenciennes, 1837 (Feltran et al., 2004) were observed. As expected the high intensity of infection by these helminthes are related to the food habit of the host. Carnivorous fish may present more possibility of infection because they occupy the top of the food web as compared to that observed for omnivorous fish like $O$. niger, which eats debris, aquatic invertebrates and insect larvae (Santos et al., 2006). In this case, they present lower risk of infection (Machado et al., 1996; Pavanelli et al., 2004) or other factors could be involved in this process.

In general, in fish, the acanthocephalan life-cycle involves a definitive host and an intermediate host which could be an arthropod amphipod, ostracod or copepod (Tantaleán et al., 2005; Thatcher, 2006). However, some species present in their life-cycle the paratenic hosts (Takemoto et al., 2004; Thatcher, 2006; Azevedo et al., 2007). Azevedo et al. (2007) argued that the principal factor regulating the prevalence and intensity of infection of acanthocephalan is the predation of the intermediate hosts. In the present study, low prevalence and mean intensity were found similar to Polymorphus sp. in A. ocellatus from the Guandu River, RJ (Azevedo et al., 2007). Sometimes, depending on the environment, acanthocephalans can reach high levels of infection in fish as commented by Martins et al. (2001). Paracavisona impudica was also reported in O. kneri from the Pantanal Mogrossense (Rego and Vicente, 1988; Eiras et al., 1995) and in O. niger from Pucallpa, Peru (Tantaleán et al., 2005). Hence, it can be inferred by these observations that this acanthocephalan species is specific to the Doradidae and Oxydoras genus.
From the intestine of only one specimen of $O$. niger from the Solimões River, 115 worms were collected, adhered to the intestinal wall that caused granuloma on their site of attachment. In O. kneri, an elevated parasitism by $P$. impudica caused fibrosis surrounding the attachment site of the proboscis (Eiras et al., 1995; Takemoto et al., 2004). Histopathological studies showed little effects of these parasites on the host, but in severe infections, can cause intestinal obstruction, malnutrition, low muscle development (Takemoto et al., 2004), as well as complete desquamation of the intestinal epithelium with severe hyperplasia and hypertrofia of the goblet cells, severe inflammatory reaction at the submucosa, oedema and mononuclear and eosinophilic infiltration (Martins et al., 2001).

Digenea are trematode endoparasites that have a complex life-cycle and are always heteroxenic generally involving two hosts. They can be found in the organs of the definitive hosts (Thatcher, 2006; Takemoto et al., 2009) or as metacercariae encysted (Bachmann et al., 2007). In the present study low parasite load by Dadaytrema sp. were observed when compared to Dadaytrema oxycephala Diesing, 1836 from P. mesopotamicus in rivers of the Pantanal Sul-Matogrossense (Santos et al., 2003). Dadaytrema oxycephala has been listed for several freshwater fish species since it is widely distributed in Brazil (Thatcher, 2006; Kohn et al., 2007). In the Amazon, it is a common parasite of the Piaractus brachypomus Cuvier, 1818 and P. granulosus (Thatcher, 2006). Nevertheless, no species has been related in $O$. niger up until now.

Martins et al. (2009) noticed that moderate infection rates by proteocephalidean cestodes have been registered in fish from several parts of the world, since this endohelminthes is distributed uniformly in several aquatic habitats (Pavanelli et al., 2004). In that opportunity, Martins et al. (2009) found high parasite load by Proteocephalus macrophallus (Diesing, 1850) Scholz, Chambrier, Prouza and Royero 1996 and P. microscopicus Woodland, 1935 in Cichla piquiti Kullander and Ferreira, 2006 from the Volta Grande Reservoir, MG, Brazil. Those authors explained that the exotic characteristic of the host, its piscivorous habit constituted by small fish of the same species could be facilitating the transmission of the cestodes.

Planktonic crustaceans, diaptomid or cyclopoid copepods serve as intermediate hosts of the Proteocephalus species. A metacestode or procercoid develops in the body cavity of these crustaceans and the definitive host, a fish, becomes infected directly after consuming them (Scholz, 1999). Consequently, proteocephalidean infection in small fish by the ingestion of these crustaceans may contribute to improve the prevalence rate and the intensity of infection in the largest hosts as the fish of carnivorous habit (Martins et al., 2009). In the present study, the prevalence (3.7\%) and mean intensity (1.0) of P. kuyukuyu was lower than that observed for $P$. macrophallus and P. microscopicus $(83.3$ and 110.8 , respectively) in C. piquiti, a piscivorous fish from the Volta Grande Reservoir, MG (Martins et al., 2009). These low indexes of infection in $O$. niger can be 
explained by the detritivorous feeding habit of this fish (Santos et al., 2006). It is likely that $O$. niger is feeding on infected crustacean from the bottom of the river favouring transmission.

Relative condition factor indicates the welfare of fish on the environment. Dias et al. (2004) and Santos and Brasil-Sato (2006) did not observe any negative effect of the infection by Rondonia rondoni Travassos, 1920 (Nematoda) on the condition factor of $P$. granulosus and Franciscodoras marmoratus Reinhardt, 1874. On the other hand, the monogenoidean Cichlidogyrus Paperna, 1960 showed a negative correlation to the prevalence and parasitism in cultured tilapia Oreochromis niloticus Linnaeus, 1758 (Lizama et al., 2007). As the parasite load increases, the body condition or welfare of fish can be affected. By contrast, in the present study, the condition factor increased as the parasite number increased together. From this point of view, it appears that the parasite infection by monogenoidean on $O$. niger do not affect negatively the fish condition. A positive correlation between the condition factor and Dadayus pacupeva Lacerda, Takemoto and Pavanelli, 2003 (Digenea) and Spinoxyuris oxydoras Peter, 1994 (Nematoda) in Metynnis lippincottianus Cope, 1870 was also related by Moreira et al. (2010). They attributed this finding to low pathogenic effect of the parasites.

In conclusion, we found in this study that the most prevalent parasite was Monogenoidea, a direct life-cycle parasite, different from the others like nematodes and digeneans endohelninthes. If the water condition favours parasite reproduction, in a few days the number of parasites can increase and cause damage to fish health. It must be also remembered that this fish are living in a natural environment and when they are exposed to stressful conditions, the relationship parasite-host-environment might alter.

Acknowledgements - The authors thank Conselho Nacional de Pesquisa e Desenvolvimento Tecnológico (CNPq), for the scholarship for the first author, for the technician scholarship (Proc. 501672/2008-7) and grants to M. Tavares-Dias (Proc. 300472/2008-0) and M.L. Martins (Proc. 301072/2007-8).

\section{References}

AZEVEDO, RK., ABDALLAH, VD. and LUQUE, JL., 2007. Ecologia da comunidade de metazoários parasitos do apaiarí Astronotusocellatus (Cope, 1872) (Perciformes: Cichlidae) do Rio Guandu, Estado do Rio de Janeiro, Brasil. Revista Brasileira de Parasitologia Veterinaria, v. 16, n. 1, p. 15-20. PMid:17588317.

BACHMANN, F., ARAÚJO GREINERT, J., BERTELLI, PW., SILVA FILHO, HH., DE LARA, NOT., GHIRALDELLI, L. and MARTINS, ML., 2007. Parasitic fauna of Pimelodusmaculatus (Osteichthyes: Pimelodidae) from the Itajaí-Açu river in Blumenau, state of Santa Catarina, Brazil. Acta Scientiarum Biological Sciences, v. 29, n. 1, p. 109-114.

BUSH, AO., LAFFERTY, KD., LOTZ, JM. and SHOSTAK, W., 1997. Parasitology meets ecology on its own terms: Margolis et al. Revisited. Journal of Parasitology, v. 83, n. 4, p. 575-583. PMid: 9267395.
DIAS, PG., FURUYA, WM., PAVANELLI, GC., MACHADO, MH. and TAKEMOTO, RM., 2004. Effect of parasitic load of Rondonia rondoni, Travassos, 1920 (Nematoda, Atrictidae) over the condition factor of thorny catfish Pterodoras granulosus (Valenciennes, 1833) (Pisces, Doradidae). Acta Scientiarum Biological Sciences, v. 26, n. 2, p. 151-156.

EIRAS, JC., TAKEMOTO, RM. and PAVANELLI, GC., 2006. Métodos de estudo e técnicas laboratoriais em parasitologia de peixes. 2nd ed. Maringá: Ed. EDUEM. 199 p.

EIRAS, JC., PAVANELLI, GC. and MACHADO, MH., 1995. Infection of Oxydoraskneri Bleecker, 1862 (Pisces, Doradidae) by the Acanthocephalan Paracavisoma impudica (Diesing, 1851) Kritcher, 1957. Memorias do Instituto Oswaldo Cruz, v. 90, n. 5, p. 629-631.

FELTRAN, RB., MARÇAL JÚNIOR, O., PINESE, JF. and TAKEMOTO, RM., 2004. Prevalência, abundância, intensidade e amplitude de infecção de nematóides intestinais em Leporinus friderici (Bloch, 1794) e L. obtusidens (Valenciennes, 1836) na represa de Nova Ponte (Perdizes, MG). Revista Brasileira de Zoociências, v. 6, n. 2, p. 169-179.

FERRAZ, E. and THATCHER, VE., 1988. Bacudacnitis grandistomis gen. et sp. nov. (Nematoda: Cucullanidae) parasite intestinal de um bagre Pseudodoras niger (Valencciennes) da Amazônia brasileira. Amazoniana, v. 10, n. 3, p. 249-253.

GRAÇA, RJ. and MACHADO, MH., 2007. Ocorrência e aspectos ecológicos de metazoários parasitos de peixes do lago do Parque do Ingá, Maringá, estado do Paraná. Acta Scientiarum Biological Science, v. 29, n. 3, p. 321-326.

KOHN, A., FERNANDES, BMM. and COHEN, SC., 2007. South Americam trematodes parasites of fishes. Fiocruz: Rio de Janeiro. 318 p.

KRITSKY, DC., THATCHER, VE. and BOEGER, WA., 1986. Neotropical Monogenoidea. 8. Revision of Urocleidoides (Dactylogyridae, Ancyroceplalinae). Proceedings of the Helminthological Society of Washington, v. 53, n. 1, p. 1-37.

LE CREN, ED., 1951. The length-weight relationship and seasonal cycle in gonadal weight and condition in the perch (Perca fluviatilis). Journal of Animal Ecology, v. 20, n. 2, p. 201-219.

LIZAMA, MLP., TAKEMOTO, RM., RANZANI-PAIVA, MJT., AYROZA, LMS. and PAVANELLI, GC., 2007. Relação parasitohospedeiro em peixes de pisciculturas da região de Assis, Estado de São Paulo, Brasil. 1. Oreochromisniloticus (Linnaeus, 1758). Acta Scientiarum Biological Sciences, v. 29, n. 2, p. 223-231.

LUQUE, JL. and POULIN, R., 2007. Metazoan parasite species richness in Neotropical fishes: hotspot sand the geography of biodiversity. Parasitology, v. 134, n. 6, p. 865-878.PMid:17291392. http://dx.doi.org/10.1017/S0031182007002272

MACHADO, MH., PAVANELLI, GC. and TAKEMOTO, RM., 1996. Structure and diversity of endoparasitic infracommunities and the trophic level of Pseudoplatystoma corruscans and Schizodonborelli (Osteichthyes) of the high Paraná River. Memorias do Instituto Oswaldo Cruz, v. 91, n. 4, p. 441-448.

MARTINS, ML., MORAES, FR., BOZZO, FR., PAIVA, AMFC. and GONÇALVES, A., 2002. Recent studies on parasitic infections of freshwater cultivated fish in the state of São Paulo, Brazil. Acta Scientiarum, v. 24, n. 4, p. 981-985.

MARTINS, ML., MORAES, FR., FUJIMOTO, RY., ONAKA, EM. and QUINTANA, CIF., 2001. Prevalence and histopathology of Neoechinorhynchus curemai Noronha, 1973 (Acanthocephala: 
Neoechinorhynchidae) in Prochilodus lineatus Valenciennes, 1836 from Volta Grande Reservoir, MG, Brazil. Brazilian Journal of Biology, v. 61, n. 3, p. 517-522. PMid:11706580. http://dx.doi. org/10.1590/S1519-69842001000300022

MARTINS, ML., PEREIRA JUNIOR, J., DE CHAMBRIER, A. and YAMASHITA, MM., 2009. Proteocephalid cestode infection in alien fish, Cichlapiquiti Kullander and Ferreira, 2006 (Osteichthyes: Cichlidae), from Volta Grande reservoir, Minas Gerais, Brazil. Brazilian Journal of Biology, v. 69, n. 1, p. 189-195. PMid:19347164. http://dx.doi.org/10.1590/S151969842009000100025

MOREIRA, LHA., YAMADA, FH., CESCHINI, TL., TAKEMOTO, RM. and PAVANELLI, GC., 2010. The influence of parasitism on the relative condition factor $(\mathrm{Kn})$ of Metynnis lippincottianus (Characidae) from two aquatic environments: the upper Parana river floodplain and Corvo and Guairacá rivers, Brazil. Acta Scientiarum Biological Sciences, v. 32, n. 1, p. 83-86.

PAVANELLI, GC., MACHADO, MH., TAKEMOTO, RM., GUIDELLI, GM. and LIZAMA, MAP., 2004. Helminth fauna of fishes: Diversity and ecological aspects. In THOMAZ, SM., AGOSTINHO, AA. and HAHN, NS. The upper Paraná River and its FloodplaIn Physical aspects, Ecology and conservation. Leiden: Backhuys Publishers. p. 309-329.

REGO, AA. and VICENTE, JJ., 1988. Excursão científica à zona do pantanal, Estado do Mato Grosso, para coletas de helmintos. Ciência e Cultura, v. 40, n. 1, p. 65-68.

REGO, AA., CHUBB, JC. and PAVANELLI, GC., 1999. Cestodes in South American freshwater teleost fishes: keys to genera and brief description of species. Revista Brasileira de Zoologia, v. 16, n. 2, p. 299-367. http://dx.doi.org/10.1590/ S0101-81751999000200003

RENO, PW., 1998. Factors involved in the dissemination of disease in fish populations. Journal of Aquatic Animal Health, v. 10, p. 160-171. http://dx.doi.org/10.1577/1548-8667(1998)010<0160:FI ITDO $>2.0 . \mathrm{CO} ; 2$

ROHDE, K., HAYWARD, C. and HEAP, M., 1995.Aspects of the ecology of metazoan ectoparasites of marine fishes. International Journal for Parasitology, v. 25, n. 8, p. 945-970. http://dx.doi. org/10.1016/0020-7519(95)00015-T

SANTOS, MD. and BRASIL-SATO, MC., 2006. Parasitic community of Fransciscodoras marmoratus (Reinhardt, 1874) (Pisces: Siluriformes, Doradidae) from the upper São Francisco River, Brazil. Brazilian Journal of Biology, v. 66, n. 3, p. 931-938. PMid:17119841. http://dx.doi.org/10.1590/S1519-69842006000500019.

SANTOS, SMC., CECCARELLI, PS. and RÊGO, RF., 2003. Helmintos em peixes do Pantanal Sul-matogrossense: primeira expedição do Programa Pantanal. Boletim Técnico do CEPTA, v. 16 , p. $15-26$.

SANTOS, G., FERREIRA, E. and ZUANON, J., 2006. Peixes comerciais de Manaus. Manaus: IBAMA/AM, Provarzea. 144 p.
SANTOS, MD., LEMOS-PITA, SRLC. and BRASIL-SATO, MC., 2007. Metazoan parasite fauna of Pimelodus maculates La Cépède, 1803 (Siluriformes, Pimelodidae) from the Guandu River, Rio de Janeiro, State, Brazil. Acta Scientiarum Biological Science, v. 29, n. 1, p. 101-107.

SCHOLZ, T., 1999. Life cycles of species of Proteocephalus, parasites of fishes in the Palearctic region: a review. Journal of Helminthology, v.73, n.1, p. 1-19. PMid:10431368. http://dx.doi. org/10.1017/S0022149X99000013

SURIANO, DM. and INCORVAIA, IS., 1995. Ancyrocephalid (Monogenoidea) parasites from siluriformes from the ParaneanPlatean icthyogeographical province in Argentine. Acta Parasitologica, v. 40, p. 113-124.

TAKEMOTO, RM., LIZAMA, MAP. andGUIDELLI, GM., 2004. Parasitos de peixes de águas continentais. In RANZANI-PAIVA, MJT., TAKEMOTO, RM. and LIZAMA, MAP. (Eds.). Sanidade de organismos aquáticos. São Paulo: Editora Varela.p. 179-197.

TAKEMOTO, RM., PAVANELLI, GC., LIZAMA, MAP., LACERDA, ACF.,YAMADA, FH., MOREIRA, LHA., CESCHINI, TL. and BELLAY, S., 2009.Diversity of parasites of fish from the upper Paraná River floodplain, Brazil. Brazilian Journal of Biology, v. 69, n. 2 (suppl.), p. 691-705. PMid:19738975. http:// dx.doi.org/10.1590/S1519-69842009000300023

TANTALEÁN, M., SÁNCHEZ, L., GÓMEZ, L. and HUIZA, A., 2005. Acantocéfalos del Peru. Revista Peruana de Biologia, v.12, n. 1 , p. $88-92$.

TAVARES-DIAS, M., LEMOS, JRG. and MARTINS, ML., 2010. Parasitic fauna of eight species of ornamental freshwater fish species from the middle Negro Riverin the Brazilian Amazon region. Revista Brasileira de Parasitologia Veterinaria, v. 19, n. 2, p. 29-33. http://dx.doi.org/10.1590/S1984-29612010000200007

TAVARES-DIAS, M., MARTINS, ML. and MORAES, FR., 2001a. Fauna parasitária de peixes oriundos de pesque-pague do município de Franca, São Paulo, Brasil. I. Protozoários. Revista Brasileira de Zoologia, v. 18, n. 1, p. 67-79. http://dx.doi. org/10.1590/S0101-81752001000500005

TAVARES-DIAS, M., MORAES, FR., MARTINS, ML. and KRONKA, SN., 2001b. Fauna parasitária de peixes oriundos de pesque-pagues do município de Franca, São Paulo, Brasil. II. Metazoários. Revista Brasileira de Zoologia, v. 18, n. 1, p. 81-95. http://dx.doi.org/10.1590/S0101-81752001000500006

THATCHER, VE., 1979. Paramphistomidae (Trematoda: Digenea) de peixes de água doce: dois novos gêneros da Colômbia e uma redescrição de Dadaytremaoxycephala (Diesing, 1836) Travassos, 1934, da Amazônia. Acta Amazônica, v. 9, n. 1, p. 203-208.

THATCHER, VE., 2006. Amazon Fish Parasites. 2nd ed. Sofia, Moscow: Pensoft Publishers. 508p.

ZAR, JH., 1999. Biostatistical Analysis. Prentice-Hall, New Jersey. 663p. 